\title{
Organization of Materials Scale
}

National Cancer Institute

\section{Source}

National Cancer Institute. Organization of Materials Scale. NCI Thesaurus. Code

C121471.

A rating scale included in the Behavior Rating Inventory of Executive Function that measures orderliness of living, work, play, and storage spaces (e.g., rooms, desks, lockers, backpacks, and bedrooms). 